\title{
Method for producing low-viscosity marine fuel oil
}

\author{
Rafail Mendybayev ${ }^{1, *}$, Nurlan Uteuliyev $^{2}$, Diana Mendybayeva ${ }^{3}$, Sairanbek Akhmetov ${ }^{1}$, and Aigul Bukanova ${ }^{1}$ \\ ${ }^{1}$ Atyrau University of Oil and Gas named after Safi Utebayeva, Atyrau, Kazakhstan \\ ${ }^{2}$ LLP "Atyrau Refinery", Atyrau, Kazakhstan \\ ${ }^{3}$ LLC " SCHLUMBERGER VOSTOK", Yuzhno-Sakhalinsk, Russia
}

\begin{abstract}
Low-viscosity marine fuel oil that is obtained from the products of residual raw materials and middle distillate fractions of oil is intended for use in ship engines instead of a diesel fuel. A real-world application of this new composition is of great importance A proposed new composition of low-viscosity marine fuel oil is created by compounding a mixture of oil distillates in accordance with the following parameters. The oil distillate mixture should contain a vacuum distillate fraction $420-490^{\circ} \mathrm{C}$, a vacuum distillate fraction $350-420^{\circ} \mathrm{C}$ and a straight-run diesel fraction $180-350^{\circ} \mathrm{C}$ taken in certain ratios. This study presents the new fuel composition and its technical advantages over previous analogues. The benefits include improvements in the coking properties and storage stability due to the stability in the pour point indicator.
\end{abstract}

\section{Introduction}

Development of technologies focused on the advancement of oil refinery and more rational use of oil products is timely and of high interest. Low-viscosity marine fuel oil (hereinafter "LMF"), obtained from the products of residual raw materials and middle distillate oil fractions, is intended for use in marine power plants in lieu of a diesel fuel. The new composition is of great practical importance [1-5]. According to the technical specifications [1, p. 3; 4, p. 2] set forth in the Russian regulatory document, technical characteristics of LMF must satisfy the conditions outlined in Table 1 (in Tables 1-8: the indicator of water content "traces" refers to the absence of water within the limits of measurement accuracy; "GOST" is an interstate regional standard of the Commonwealth of Independent States of the Eurasian Economic Union).

The article presents the development and the invention of a new method of producing LMF, and a number of its technical advantages over previously known analogues related to the coking index and storage stability [4].

\section{Literature Review}

Many studies [1-5, 7-8, 12-18] are devoted the development of marine fuel compositions $[1-5,7-8,12-$ 18], given its practical significance as well as the difficulty of estimating its technical parameters which are influenced by many factors.

One of the previously known compositions of LMF [2], close to the proposed one in this article, is an oil distillate mixture comprised of five components atmospheric gasoil fraction $240-450^{\circ} \mathrm{C}$, forecut vacuum fraction $200-400^{\circ} \mathrm{C}$, coking distillate fractions 160 $400^{\circ} \mathrm{C}$, catalytic cracking of fraction $180-400^{\circ} \mathrm{C}$ and of diesel fuel fraction $160-360^{\circ} \mathrm{C}$ in the following mass ratio:

$\begin{array}{lr}\text { fraction } 240 \text { to } 450 \mathrm{oC} & 5 \div 15 \\ \text { fraction } 200 \text { to } 400 \mathrm{oC} & 5 \div 25 \\ \text { fraction } 160 \text { to } 400 \mathrm{oC} & 5 \div 30 \\ \text { fraction } 180 \text { to } 400 \mathrm{oC} & 5 \div 60 \\ \text { fraction } 160 \text { to } 360 \mathrm{oC} & \text { up to } 100 .\end{array}$

The objective of the aforementioned analogue is to obtain the following technical results: increase in the yield of LMF, improvements in the lubricity, heat of combustion and corrosion resistance.

The closest analogue (prototype) is LMF [3], which is an oil distillate mixture of the following fractions: (i) fraction $160-360^{\circ} \mathrm{C}$ of atmospheric distillation; (ii) fraction $240-450^{\circ} \mathrm{C}$ of atmospheric distillation that contains fractions boiling in the range of $240-360^{\circ} \mathrm{C}$ and $360-450^{\circ} \mathrm{C}$ at a mass ratio of $(80 \div 90):(20 \div 10)$; (iii) fraction $240-550^{\circ} \mathrm{C}$ of secondary vacuum distillation of fuel oil that contains fractions $240-360^{\circ} \mathrm{C}$ and $360-550^{\circ} \mathrm{C}$ at a mass ratio of $(80 \div 90):(20 \div 10)$; whereby the three main components are at the following mass \% ratio:

fraction 240 to $450 \mathrm{oC}$

of atmospheric distillation $\quad 5 \div 30$

fraction 240 to $550 \mathrm{oC}$ of secondary

vacuum distillation of fuel oil $5 \div 15$

fraction 160 to $360 \mathrm{oC}$ of

atmospheric distillation

up to 100 .

The objective of this prototype is to obtain the following technical results: improvements in the lubricity of the fuel and its corrosive activity.

\footnotetext{
* Corresponding author: menraf55_g@mail.ru
} 
The common disadvantages of these known objects are an increased coking rate and reduced storage stability due to an increase in the pour point over time (shelf life).

Oil is a non-homogeneous chemical substance with a complex chemical composition. Oil is comprised of a large number of various substances: hydrocarbons and different compounds including sulfurous, oxygen, nitrogenous and others $[5-8,10]$. This also applies to LMF [1-5] derived from oil. Hence, modern theories cannot accurately estimate the technical parameters of oil and fuel compositions (in particular, coking and pour point), since it is not feasible to take into account all the influencing factors. Currently, new fuel compositions are being developed empirically, by trial and error.

As known [9], coking characterizes the tendency of a petroleum product to form coke. A coke residue indicates a carbonaceous residue. In engines, it is formed when fuel is heated at high temperatures without air access. The higher is the coking capacity of the fuel, the more intense is the formation of carbon deposits, which impairs the operation and efficiency of engines.

It is known [10] that the pour point of fuel determines the conditions of storage, transportation, discharge and transfer of fuel.

An increase in the pour point of fuel during storage occurs due to the interaction of its constituent substances and, as a consequence, a change in the moleculardispersed structure of the fuel. This property of fuels complicates its use and does not guarantee an appropriate quality during storage and transportation. Since all the factors influencing the pour point of the fuel (storage duration, physicochemical changes occurring during storage) cannot be taken into account, it is not possible to estimate the pour point or find its value in time. Therefore, considering the instability of the pour point, the standards for fuels containing heavy fractions require warranties from manufacturers, whereby the pour point should not exceed a certain value established by the standard after three months. The warranty period is based on experimental data. The regression necessitates the production of fuel with a quality margin for this indicator.

Chemical changes in the fuel that occur during transportation or storage are associated with the oxidation of mainly its constituent hydrocarbons. This leads to the formation of deposits of oxidation products that deteriorate performance of the fuel.

Fuel oxidation, which occurs in the presence of atmospheric oxygen, is a complex multistage free radical process. For example, olefinic hydrocarbons and aromatic hydrocarbons with a double bond in the side chain have low chemical stability. The most resistant to oxidation are paraffinic hydrocarbons of normal structure and aromatic hydrocarbons. Non-hydrocarbon components also affect the chemical stability of the fuel.

The reasons behind the indicated disadvantages (coking capacity and pour point) of the abovementioned analogues are complex and have not been studied. But apparently, one of the causal factors is the increased content of heavy fractions in these known analogues compared to the proposed object. The more heavy fractions there are in the fuel, the higher the coking and pour point will be.

A new composition of LMF is created by compounding a mixture of oil distillates containing a vacuum distillate fraction $420-490^{\circ} \mathrm{C}$, a vacuum distillate fraction $350-420^{\circ} \mathrm{C}$, and a straight-run diesel fraction $180-350^{\circ} \mathrm{C}$ taken in certain proportions. The results presented in this study substantiate the technical advantages of the new fuel composition compared to previously known analogues. In particular, these advantages include improvements in the coking index and stability during storage as a result of the pour point indicator's stability.

The technical proposal is to create a new composition of LMF with an objective to obtain the following technical results that improve operational properties of LMF: improving the coking property and stability during storage as a result of the pour point indicator's stability. Thus, the proposed object will solve and eliminate previously mentioned disadvantages of previously known analogues, while complying with all the characteristics specified in the industry document $[1, p .3$; 4, p. 2].

\section{Materials and methods}

To solve the assigned technical problem, a new LMF composition is created by compounding a mixture of oil distillates, specifically, a vacuum distillate fraction 420$490^{\circ} \mathrm{C}$, vacuum distillate fraction $350-420^{\circ} \mathrm{C}$, and a straight-run diesel fraction $180-50^{\circ} \mathrm{C}$ at the following mass $\%$ ratio of components:

fraction of vacuum

distillate 420 to $490^{\circ} \mathrm{C}$

fraction of vacuum

distillate 350 to $420^{\circ} \mathrm{C}$

straight-run diesel fraction

180 to $350^{\circ} \mathrm{C}$

The selected prototype is similar to the proposed object in terms of the number of mixed components (three) and with the largest part being diesel fraction in the mixture (in the case of the prototype, fraction 160$360^{\circ} \mathrm{C}$, and in the case of the proposed object, fraction $180-350^{\circ} \mathrm{C}$ ). However, in comparison with the known compositions of LMF indicated above, the claimed composition of LMF represents a new and previously unknown combination of components taken in certain ratios. This distinguishes the proposed composition of LMF from previously known compositions both from a qualitative and quantitative point of view. The qualitative and quantitative differences of the proposed object allow to achieve a new technical result declared herein.

Experimental confirmation of the proposed solution is carried out by comparing under the same conditions the results of realizations of the prototype, the proposed solution and control experiments. Control experiments are undertaken with control compositions to identify and substantiate the declared area of component ratios.

The technical indicators of the compositions are determined by the standard test methods indicated in 
Table 1. Technical specifications TS 38.101567-2005. Low-viscosity marine fuel oil.

\begin{tabular}{|l|c|c|}
\hline \multicolumn{1}{|c|}{ Indicator name } & Normal value & Trial methods \\
\hline Kinematic viscosity at $20^{\circ} \mathrm{C}, \mathrm{mm} / \mathrm{s}^{2}, \mathrm{max}$ & 11.4 & GOST 33-82 \\
Cetane number & 40 & GOST 3122-67 \\
Closed Cup Flash Point, ${ }^{\circ} \mathrm{C}$, min & 62 & GOST 6356-75 \\
Pour point, ${ }^{\circ} \mathrm{C}$, max & minus 10 & GOST 20287-74 \\
Mass fraction of sulfur, \%, max: & & \\
I type & 0.5 & GOST 19121-73 \\
II type & 1.0 & GOST 19121-73 \\
III type & 1.5 & GOST 19121-73 \\
Mass fraction of mercaptan sulfur, \%, max & 0.025 & GOST 17323-71 \\
Mass fraction of water, \% & traces & GOST 2477-65 \\
Coking, $\%$, max & 0.2 & GOST 19932-99 \\
The content of water-soluble acids and alkalis & absence & GOST 6307-75 \\
Ash content, $\%$, max & 0.01 & GOST 1461-75 \\
Mass fraction of mechanical impurities, $\%$, max & 0.02 & GOST 6370-83 \\
Density at $20^{\circ} \mathrm{C}, \mathrm{kg} / \mathrm{m}^{3}$, max & 890 & GOST 3900-85 \\
Iodine number, grams of iodine per $100 \mathrm{~g}$ of fuel, max & 20 & GOST 2070-82 \\
\hline
\end{tabular}

Table 1, or other alternative international standard methods. For instance, (i) density can be determined by ASTM D4052 (ASTM-American Society for Testing and Materials) [12, 14-17]; (ii) kinematic viscosity by ASTM D445 [12-17]; (iii) pour point by ASTM D97 [12, 14-16]; (iv) flash point by ASTM D93 [12]; (v) acid number by ASTM D664 [12, 18]; (vi) water content by ASTM D95 [12]; (vii) sulfur content by ASTM D4294 [12]; (viii) ash content by ASTM D482 [12]; (ix) cetane number by ASTM D613 [13] and others [13, 18].

Oils of Western Kazakhstan - Karazhanbas, Kalamkas and other oils - were taken and studied as the initial oil for obtaining LMF compositions.

\section{Results and Discussions}

Tables $2-8$ present data from the many experiments carried out by the research team. This data is necessary and sufficient to disclose the proposed object and to identify and substantiate the proposed component ratios, using the example of LMF compositions obtained from Karazhanbas oil by compounding the pertinent fractions. Fractions of distillates are obtained from Karazhanbas oil with a density at $20^{\circ} \mathrm{C}$ of $937 \mathrm{~kg} / \mathrm{m}^{3}$, with chloride salt content of $45 \mathrm{mg} / \mathrm{dm}^{3}$, and water content of 0.03 mass $\%$.

Table 2 shows the composition of the LMF compositions studied for the case of the prototype. The compositions were taken from the boundary ratios and one internal ratio to ensure sufficiency of the disclosure in the material of the newly claimed LMF.
Table 2. The case of the prototype - the composition of the LMF compositions.

\begin{tabular}{|c|c|c|c|}
\hline \multirow{2}{*}{$\begin{array}{l}\text { Componen } \\
\text { t name }\end{array}$} & \multicolumn{3}{|c|}{$\begin{array}{l}\text { Component content in the composition of the } \\
\text { prototype, mass } \%\end{array}$} \\
\hline & $\begin{array}{c}\text { Composition } \\
1\end{array}$ & $\begin{array}{c}\text { Composition } \\
2\end{array}$ & $\begin{array}{c}\text { Composition } \\
3\end{array}$ \\
\hline $\begin{array}{l}\text { Fraction } \\
240 \text { to } \\
450^{\circ} \mathrm{C} \text { of } \\
\text { atmospheric } \\
\text { distillation }\end{array}$ & 5 & 20 & 30 \\
\hline $\begin{array}{l}\text { Fraction } \\
240 \text { to } \\
550^{\circ} \mathrm{C} \text { of } \\
\text { secondary } \\
\text { vacuum } \\
\text { distillation } \\
\text { of fuel oil }\end{array}$ & 5 & 10 & 15 \\
\hline $\begin{array}{l}\text { Fraction } \\
160 \text { to } \\
360^{\circ} \mathrm{C} \text { of } \\
\text { atmospheric } \\
\text { distillation }\end{array}$ & 90 & 70 & 55 \\
\hline
\end{tabular}

Table 3 shows the composition of the LMF compositions studied for the case of the proposed object. Similarly, the compositions were taken from the boundary ratios and one internal ratio to ensure sufficiency of the disclosure in the material of the newly claimed LMF. 
Table 3. The case of the proposed object - the composition of the LMF compositions.

\begin{tabular}{|c|c|c|c|}
\hline \multirow{2}{*}{$\begin{array}{c}\text { Component } \\
\text { name }\end{array}$} & \multicolumn{3}{|c|}{$\begin{array}{l}\text { Component content in the composition of } \\
\text { the proposed object, mass \% }\end{array}$} \\
\hline & $\begin{array}{c}\text { Composition } \\
4\end{array}$ & $\begin{array}{c}\text { Composition } \\
5\end{array}$ & $\begin{array}{c}\text { Composition } \\
6\end{array}$ \\
\hline $\begin{array}{l}\text { Fraction of } \\
\text { vacuum } \\
\text { distillate } 420 \\
\text { to } 490^{\circ} \mathrm{C}\end{array}$ & 2 & 7 & 15 \\
\hline $\begin{array}{c}\text { Fraction of } \\
\text { vacuum } \\
\text { distillate } 350 \\
\text { to } 420^{\circ} \mathrm{C} \\
\end{array}$ & 3 & 10 & 20 \\
\hline $\begin{array}{c}\text { Straight-run } \\
\text { diesel } \\
\text { fraction } 180 \\
\text { to } 350^{\circ} \mathrm{C} \\
\end{array}$ & 95 & 83 & 65 \\
\hline
\end{tabular}

Table 4 shows the composition of the control compositions analyzed in control experiments to identify and substantiate the declared range of component ratios (the boundaries of the stated ratios). From a qualitative point of view, the control compositions contained the same types of components as the claimed object. But the quantitative ratio of the components in the control compositions did not conform to the declared ratio. The quantitative content of at least one of the components in the control experiments was not a part of the declared range of ingredient ratios and was taken from the border area in relation to the stated ratios (Table 4). The control compositions showed (Table 7) that the achievement of the declared result was not observed for them, and they did not meet the requirements for LMF indicators per the normative document $[1$, p.3; 4, p. 2]. However, the control compositions helped to identify and substantiate the boundaries of the stated ratios.

Table 4. The composition of the control compositions.

\begin{tabular}{|l|c|c|c|c|c|c|}
\hline \multirow{2}{*}{$\begin{array}{c}\text { Component } \\
\text { name }\end{array}$} & \multicolumn{5}{|c|}{$\begin{array}{c}\text { Component content in the composition } \\
\text { of the control compositions 7-12 (C 7- } \\
\text { 12), mass \% }\end{array}$} \\
\cline { 2 - 7 } & C7 & C8 & C9 & C10 & C11 & C12 \\
\hline $\begin{array}{l}\text { Fraction of } \\
\text { vacuum } \\
\text { distillate } 420 \text { to } \\
490^{\circ} \mathrm{C}\end{array}$ & 1 & 16 & 8 & 2 & 15 & 1 \\
\hline $\begin{array}{l}\text { Fraction of } \\
\text { vacuum } \\
\text { distillate } 350 \text { to } \\
420^{\circ} \mathrm{C}\end{array}$ & 9 & 4 & 2 & 21 & 21 & 3 \\
\hline $\begin{array}{l}\text { Straight-run } \\
\text { diesel fraction } \\
180 \text { to } 350^{\circ} \mathrm{C}\end{array}$ & 90 & 80 & 90 & 77 & 64 & 96 \\
\hline
\end{tabular}

Table 5 shows the results of determining the indicators for LMF compositions in the case of a prototype per the document $[1$, p. $3 ; 4$, p. 2].
Table 5. The case of the prototype - the results of determining the indicators of the compositions.

\begin{tabular}{|l|c|c|c|}
\hline \multirow{2}{*}{$\begin{array}{l}\text { Indicators determined in } \\
\text { the experiment }\end{array}$} & \multicolumn{3}{|c|}{$\begin{array}{c}\text { Indicator value for } \\
\text { compositions }\end{array}$} \\
& $\mathbf{1 - 3}$ (C 1-3) of the prototype \\
\cline { 2 - 4 } C1 & C2 & C3 \\
\hline $\begin{array}{l}\text { Kinematic viscosity at } \\
20^{\circ} \mathrm{C}, \mathrm{mm} / \mathrm{s}^{2}\end{array}$ & 8.7 & 10.1 & 11.2 \\
\hline Cetane number & 43 & 44 & 46 \\
\hline Closed Cup Flash Point, ${ }^{\circ} \mathrm{C}$ & 65 & 72 & 78 \\
\hline Pour point, ${ }^{\circ} \mathrm{C}$ & -15 & -13 & -10 \\
\hline Mass fraction of sulfur, \% & 0.46 & 0.99 & 1.4 \\
\hline $\begin{array}{l}\text { Mass fraction of mercaptan } \\
\text { sulfur, \% }\end{array}$ & 0.0088 & 0.0049 & 0.0020 \\
\hline Mass fraction of water, \% & traces & traces & traces \\
\hline Coking, \% & 0.162 & 0.173 & 0.191 \\
\hline $\begin{array}{l}\text { Content of water-soluble } \\
\text { acids and alkalis }\end{array}$ & absence & absence & absence \\
\hline Ash content, \% & 0.004 & 0.007 & 0.009 \\
\hline $\begin{array}{l}\text { Mass fraction } \\
\text { mechanical impurities, \% }\end{array}$ & absence & absence & absence \\
\hline Density at 20 ${ }^{\circ} \mathrm{C}, \mathrm{kg} / \mathrm{m}^{3}$ & 868 & 872 & 876 \\
\hline $\begin{array}{l}\text { Iodine number, g of iodine } \\
\text { per } 100 \mathrm{~g} \text { of fuel }\end{array}$ & 6.5 & 9.0 & 10.8 \\
\hline
\end{tabular}

Table 6 shows the results of determining the indicators for LMF compositions in the case of the proposed object per [1, p.3; 4, p. 2].

Table 6. The proposed object - the results of determining the indicators of compositions.

\begin{tabular}{|l|c|c|c|}
\hline \multirow{2}{*}{$\begin{array}{c}\text { Indicators determined in } \\
\text { the experiment }\end{array}$} & \multicolumn{3}{c|}{$\begin{array}{c}\text { Indicator value for } \\
\text { compositions } \\
\mathbf{1 - 3}(\mathbf{C ~ 1 - 3 )} \text { of the prototype }\end{array}$} \\
\cline { 2 - 4 } C1 & C2 & C3 \\
\hline $\begin{array}{l}\text { Kinematic viscosity at } \\
20^{\circ} \mathrm{C}, \mathrm{mm} / \mathrm{s}^{2}\end{array}$ & 8.5 & 9.2 & 10.6 \\
\hline Cetane number & 43 & 44 & 46 \\
\hline Closed Cup Flash Point, ${ }^{\circ} \mathrm{C}$ & 63 & 67 & 74 \\
\hline Pour point, ${ }^{\circ} \mathrm{C}$ & -18 & -16 & -12 \\
\hline Mass fraction of sulfur, \% & 0.32 & 0.64 & 1.13 \\
\hline $\begin{array}{l}\text { Mass fraction of mercaptan } \\
\text { sulfur, \% }\end{array}$ & 0.0098 & 0.0074 & 0.0039 \\
\hline Mass fraction of water, \% & traces & traces & traces \\
\hline Coking, \% & 0.062 & 0.083 & 0.103 \\
\hline $\begin{array}{l}\text { Content of water-soluble } \\
\text { acids and alkalis }\end{array}$ & absence & absence & absence \\
\hline Ash content, \% & 0.002 & 0.006 & 0.008 \\
\hline $\begin{array}{l}\text { Mass fraction } \\
\text { mechanical impurities, \% }\end{array}$ & absence & absence & absence \\
\hline Density at $20^{\circ} \mathrm{C}, \mathrm{kg} / \mathrm{m}^{3}$ & 867 & 869 & 874 \\
\hline $\begin{array}{l}\text { Iodine number, g of iodine } \\
\text { per } 100 \mathrm{~g} \text { of fuel }\end{array}$ & 5.9 & 7.4 & 9.6 \\
\hline
\end{tabular}

Table 7 shows the results of determining the indicators for control compositions per [1, p.3; 4, p. 2].

Underlined values in Table 7 indicate that the indicators for control compositions do not meet the regulatory requirements of the document $[1$, p. $3 ; 4$, p. 2]. In addition, data presented in Tables 5-7 was obtained immediately after preparation of the compositions without long-term storage.

The following conclusions are made based on the data presented in Tables 1-7. 
Table 7. The control compositions - the results of determining the indicators.

\begin{tabular}{|l|c|c|c|c|c|c|}
\hline \multirow{2}{*}{ Indicators determined in the experiment } & \multicolumn{5}{|c|}{ Indicator value for control compositions 7-12 (K 7-12) } \\
\cline { 2 - 7 } & $\mathrm{C} 7$ & $\mathrm{C} 8$ & $\mathrm{C} 9$ & $\mathrm{C} 10$ & $\mathrm{C} 11$ & $\mathrm{C} 12$ \\
\hline Kinematic viscosity at $20^{\circ} \mathrm{C}, \mathrm{mm} / \mathrm{s}^{2}$ & 8.6 & 9.3 & 8.7 & 9.6 & 11.0 & 8.2 \\
Cetane number & $\underline{39}$ & 44 & 43 & 45 & 46 & $\underline{38}$ \\
Closed Cup Flash Point, ${ }^{\circ} \mathrm{C}$ & 65 & 69 & 65 & 70 & 75 & $\underline{60}$ \\
Pour point, ${ }^{\circ} \mathrm{C}$ & -16 & -15 & -16 & -14 & -12 & -18 \\
Mass fraction of sulfur, \% & 0.46 & 0.72 & 0.45 & 0.89 & 1.15 & 0.30 \\
Mass fraction of mercaptan sulfur, \% & 0.0089 & 0.0068 & 0.0088 & 0.0063 & 0.0037 & 0.0100 \\
Mass fraction of water, \% & traces & traces & traces & traces & traces & traces \\
Coking, \% & 0.134 & 0.145 & 0.137 & 0.148 & 0.158 & 0.129 \\
Content of water-soluble acids and alkalis & absence & absence & absence & absence & absence & absence \\
Ash content, \% & 0.004 & $\underline{0.014}$ & $\underline{0.012}$ & 0.007 & $\underline{0.017}$ & 0.002 \\
Mass fraction of mechanical impurities, \% & absence & absence & absence & absence & absence & absence \\
Density at $20^{\circ} \mathrm{C}, \mathrm{kg} / \mathrm{m}^{3}$ & 868 & 870 & 869 & 873 & 874 & 866 \\
Iodine number, $\mathrm{g}$ of iodine per $100 \mathrm{~g}$ of fuel & 6.4 & 7.8 & 6.6 & $\underline{21.4}$ & $\underline{21.7}$ & 5,8 \\
\hline
\end{tabular}

1. The parameters' values of the prototype and the proposed object after the preparation of LMF meet the regulatory requirements set forth in the document $[1, \mathrm{p} .3$; 4, p. 2]. In the case of control compositions, each control composition has some individual values of indicators that do not meet the standards set forth in the document $[1$, p.3; 4, p. 2]. In general, all the tested control compositions cannot be used as LMF that meet the standard.

2. In comparison to the prototype, the value of the coking index in the proposed object decreases significantly - on average by two times, which improves operational properties of LMF.

Data in Table 8 shows the effect of storage time on the pour point of LMF compositions in the cases of the prototype and the proposed object. Storage was carried out under the same conditions at $20^{\circ} \mathrm{C}$. (Respective data for control compositions is not provided because they cannot be used as LMF that meet the standard as was indicated above).

Table 8. Effect of storage time on the pour point of LMF compositions in the prototype and the proposed object.

\begin{tabular}{|l|c|c|c|c|c|c|}
\hline \multirow{2}{*}{$\begin{array}{c}\text { Storage } \\
\text { period }\end{array}$} & \multicolumn{6}{|c|}{$\begin{array}{c}\text { Pour point value of the } \\
\text { Compositions 1-6 (C 1-6), }{ }^{\mathbf{0}} \mathbf{C}\end{array}$} \\
\cline { 2 - 7 } & $\mathbf{C 1}$ & $\mathbf{C 2}$ & $\mathbf{C 3}$ & $\mathbf{C 4}$ & $\mathbf{C 5}$ & $\mathbf{C 6}$ \\
\hline $\begin{array}{l}\text { On the day of } \\
\text { preparation of } \\
\text { the }\end{array}$ & & & & & & \\
composition & & & & & & \\
1 month & -15 & -13 & -10 & -18 & -16 & -12 \\
2 months & -13 & -12 & -10 & -18 & -16 & -12 \\
3 months & -10 & -11 & -9 & -18 & -16 & -12 \\
4 months & -9 & -9 & -8 & -18 & -16 & -12 \\
5 months & -9 & -9 & -8 & -18 & -16 & -12 \\
6 months & -9 & -9 & -8 & -18 & -16 & -12 \\
& & & & & & \\
\hline
\end{tabular}

From the data in Table 8 , it can be concluded that the stability of the pour point is observed during the storage period in the case of the proposed object. On the other hand, in the case of the prototype, the pour point is unstable, and after three months of storage, the pour point increases and exceeds the required norm of minus $10^{\circ} \mathrm{C}$.

In addition it is worth noting that there are many additives for fuels - antioxidant, anticorrosive, depressor, antiwear and others, which are added to fuel in small concentrations to improve quality and performance [11]. Separate additives can be used to improve certain indicators of LMF. However, this requires appropriate research, since, for example, additives worsen (increase) the coking property compared to a lack thereof [9].

\section{Conclusions}

Therefore, as a result of this research which was undertaken with an objective to eliminate disadvantages of previously known analogues associated with coking and pour point, a new method for obtaining LMF has been developed. The method stipulates compounding a mixture of oil distillates, containing a vacuum distillate fraction $420-490^{\circ} \mathrm{C}$, a vacuum distillate fraction 350 $420^{\circ} \mathrm{C}$, a straight-run diesel fraction $180-350^{\circ} \mathrm{C}$, according to the following mass \% ratio of components:

fraction of vacuum

distillate 420 to $490^{\circ} \mathrm{C}$

fraction of vacuum

distillate 350 to $420^{\circ} \mathrm{C}$

straight-run diesel fraction

180 to $350^{\circ} \mathrm{C}$

In addition, the operational properties of LMF are improved as a result of improvements in the index of coking and storage stability due to the stability in the pour point indicator.

\section{References}

1. N.K. Kondrasheva N.K., D.O. Kondrashev, K.E. Stankevich, S.V. Popova, Valid Nasif, Optimization of the component composition of low-viscosity marine fuel, Neftegazovoye delo, No. 1, p. 1-9, (2007), [in Russian]. 
2. Patent RU № 2076138 (published on March 27, 1997), [in Russian].

3. Patent RU № 2058372 (published April 20, 1996), [in Russian].

4. Patent KZ № 28573 (published on May 15, 2015), [in Russian].

5. N.K. Kondrashova, A.F. Akhmetov, Marine Fuel, Izdatel'stvo «Gilem», Ufa, 139 p., (2001), [in Russian].

6. V.M. Kapustin, A.A. Gureev, Oil Refining Technology, Part Two, Physicochemical Processes, Moscow: Chemistry, 400 pp., (2015), [in Russian].

7. K. Abdel-Aal Hussein, A. Aggour Mohamed, A. Fahim Mohamed, Petroleum and Gas Field Processing, 2nd Edition, CRC Press, 412 p., (2016).

8. Springer Handbook of Petroleum Technology / ed. by C.S. Hsu, P.R. Robinson, Springer, 1247 p., (2017).

9. Petroleum products. Determination of coking by the Conradson method. GOST 19932-99. / [Electronic resource]. - Access mode: http://docs.cntd.ru/document/1200006072 (date of access: 11.01.2021), [in Russian].

10. I.N. Diyarov, I. Yu. Batueva, A.N. Sadykov, N.L. Solodova, Oil Chemistry. Guide to laboratory studies: Textbook for universities, L .: Chemistry, 240 p., (1990), [in Russian].

11. K.K. Papok, N.A. Ragozin, Dictionary of fuels, oils, lubricants, additives and special fluids (chemical dictionary), Ed. 4th. revised and supplemented, M .: Chemistry, 392 p., (1975), [in Russian].

12. Patent US 8,987,537 B1, (date of publication: Mar. 24, 2015).

13. Patent EP 2038381 B1, (date of publication: 25.01.2017).

14. Patent US $10,443,006$ B1, (date of publication: Oct. 15, 2019).

15. Patent US 10,597,594 B1, (date of publication: Mar. 24, 2020).

16. Patent US 10,781,391 B2, (date of publication: Sep. 22, 2020).

17. Patent US 10,836,970 B2, (date of publication: Nov. 17, 2020).

18. Patent US 9,109,176 B2, (date of publication: Aug. $18,2015)$. 